\title{
THE USE OF Senecio cineraria PLANTS SPRAYED WITH CITRIC ACID FOR LEAD POLLUTION PHYTOREMEDIATION
}

(Received:24 2 .2019)

\author{
By \\ N. A. El-Shanhorey, Amani I. Adam* and Fatma EL-zahraa H. El-Tony* \\ Botanical Gardens Research Department, *Ornamental Plants Research Department, \\ Horticulture Research Institute, Agricultural Research Centre, Alexandria, Egypt.
}

\begin{abstract}
The present study was carried out at Antoniadis Research Branch, Horticulture Research Institute A.R.C. Alexandria, Egypt during 2017 and 2018 seasons. This study aim to investigate the effect of for levels of lead 0,100, 200 and $300 \mathrm{ppm}$ ) in water irrigation and three different concentrations of citric acid $(0,250$ and $500 \mathrm{ppm})$ as foliar application on the vegetative growth and chemical composition of Senecio cineraria. Moreover, this investigation aim to study the ability of using Senecio cineraria as lead phytoremediation.

The results exhibited significant reduction in all vegetative parameters as affected by lead concentration treatments. On the other hand, significant increment in vegetative growth parameters was detected by using 500 ppm citric acid. Concerning chlorophyll and carbohydrates contents, the highest significant values were obtained under tap water irrigation ( 0 and 0 levels of lead and citric acid).

Moreover,the results showed no significant effect of the combinations (interaction) between lead and citric acid concentrations on vegetative growth parameters. Meanwhile, the results showed, the highest amount of lead sentient in leaves and roots was detected under the treatments combination (300 ppm load 0 citric acid).

Finally, the results also showed, it is possible to use Senecio cineraria hands as lead phytoremediation by using citric acid (300 ppm) as foliar application.
\end{abstract}

Key words: Senecio cineraria - Lead-Citric acid - Phytoremediation.

\section{INTRODUCTION}

Phytoremediation has become an effective and affordable technological solution used to extract or remove inactive metals and metal pollutants from contaminated soils. Phytoremediation is the use of plants to clean up a contamination from soils, sediments and water. This technology is environment friendly and potentially cost effective. Plants with exceptional metal-accumulating capacity are known as hyperaccumulator plants (Choruk et al., 2006). Plants need trace amounts of heavy metals but their excessive availability may cause plant toxicity (Sharma et al., 2006). Lead is a toxic heavy metal that has an environmental concern (Mahler et al., 1981). There are many sources of environmental lead pollution, including fuel combustion, industrial sludges, phosphate fertilizers, and mine tailings (Unhalekhana and Kositanont, 2008).

Lead is one of the main sources of environmental pollution. Many studies have shown that lead inhibits metabolic processes such as nitrogen assimilation, photosynthesis, respiration, water uptake, and transcription (Kurepa et al., 1997 and Boussama et al., 1999). Lead may inactivate various enzymes by binding to their SH-groups (Rauser, 1995), and can intensify the processes of reactive oxygen species (ROS) production leading to oxidative stress (Cuypers et al., 1999; Prasad et al., 1999). In addition, lead can negatively affect mitochondria structure by decreasing the number of mitochondrial cristae, which in turn can lower the capability of oxidative phosphorylation (Malecka et al., 2001).

Endogenous organic acids are the source of both carbon skeleton and energy for cells and are used in the respiratory cycle and other biochemical pathways (Da Silva, 2003). Citric acid is a six carbon organic acid, having a central role in citric acid cycle in mitochondria that creates cellular energy by phosphorylative oxidation reactions. It is created by addition of acetyl-CoA to oxaloacetic acid that is converted to succinate and malate in next steps (Wills et al., 1981). 
Senecio cineraria var. Dusty miller is a subshrub. It is a species in the genus Senecio which contains approximately 1562 to 2834 species and belongs to the family Asteraceae. This family includes members that have lead hyperaccumulators which reflect their potential to survive and sequester high level of lead in tissues (from several thousands of $\mathrm{mg} / \mathrm{kg}$ up to $5 \%$ of dry biomass) without exhibiting phytotoxicity (Prasad, 2005). The plant height reaches 40 to $60 \mathrm{~cm}$. It is grown primarily for its attractive silver-gray foliage rather than its yellow flowers. In fact, most gardeners prefer to cut off the flowers to encourage leaf growth. The plant is often grown in formal bedding schemes, but looks equally effective in informal or cottage-style designs. Dusty Miller is a nice addition to a colorful container garden, and makes a nice edging (Christoper, 2003).

The aim of this work was to study the growth of Senecio cineraria plants irrigated with lead contaminated water and the possible effect of citric acid spray on alleviating lead pollution stress, and to test Senecio cineraria as a phytoremediator plant.

\section{MATERIALS AND METHODS}

The present study was carried-out at Antoniades Research Branch, Horticulture Research Institute, Agricultural Research Center, Alexandria, Egypt during the two successive seasons of 2017 and 2018.

On $1^{\text {st }}$ April, homogenous seedlungs of Senecio cineraria var. Dusty Miller with average leaf number of 25- 27 were planted individually in plastic pots (14 cm diameter) filled with a mixture of sand and clay1:1(v/v). The physical and chemical properties of the used soil are shown in Table (1) as described by Jackson (1958). at $90 \%$.The reduction in the moisture level was determined by using Moisture Tester Model KS-DI (Gypsum Block) during growing season. At the end of the experiment the total amount of water irrigation for each pot was calculated and presented in Table (2). Every plant received about 36 liters per pot of contaminated water. The field capacity of the mixture soil was determined by the pressure Cooker method at 1/3 atm., as described by Israelsen and Hansen (1962). The plants were also sprayed with citric acid at concentrations of 0,250 and 500 ppm, monthly from $1^{\text {st }}$ June till the $1^{\text {st }}$ September (Four times per season). Control plants were sprayed with tap water. The plants were collected on $1^{\text {st }}$ November in both seasons.

The plants received NPK requirements using a fertilizer (Milagro Amino leaf 20-20-20) at the rate of $2 \mathrm{~g} /$ pot. Fertilization was repeated every 30 days throughout the growing season (from $15^{\text {th }}$ May till $15^{\text {th }}$ September). In addition, all other agricultural practices were performed as usual.

Data recorded :

(1) The following vegetative growth parameters recorded: number of leaves per plant, leaves area $\left(\mathrm{cm}^{2}\right)$ according to Koller (1972), leaf dry weight per plant $(\mathrm{g})$, tillers number per plant, stem height $(\mathrm{cm})$, stem diameter $(\mathrm{cm})$, stem dry weight $(\mathrm{g})$, root length $(\mathrm{cm})$ and root dry weight $(\mathrm{g})$.

(2) Chemical analysis determination:

Total chlorophylls content were determined as a SPAD unites from the fresh leaves of the plants for the different treatments under the experiment at the end of the season using Minolta (chlorophyll meter) SPAD 502 according to Yadava (1986).

Total carbohydrates percentage in the dry leaves was determined according to Dubios et al. (1956).

Determination of lead content: Plant samples

Table (1):The physical and chemical properties of the used mixture soil for the two seasons.

\begin{tabular}{|l|c|c|c|c|c|c|c|c|}
\hline \multirow{2}{*}{$\mathbf{p H}$} & \multirow{2}{*}{$\begin{array}{c}\mathbf{E C} \\
\mathbf{d s} / \mathbf{m}\end{array}$} & \multicolumn{4}{|c|}{ Cations (meq/l) } & \multicolumn{3}{c|}{ Anions (meq//) } \\
\cline { 3 - 9 } & & $\mathbf{C a}^{++}$ & $\mathbf{M g}^{++}$ & $\mathbf{N a}^{+}$ & $\mathbf{K}^{+}$ & $\mathbf{H C O}_{3}^{-}$ & $\mathbf{C l}$ & $\mathbf{S O}_{4}^{--}$ \\
\hline $\mathbf{8 . 0 8}$ & $\mathbf{2 . 5 3}$ & 18.20 & 14.20 & 23.91 & 4.49 & 7.20 & 21.00 & 27.10 \\
\hline \multicolumn{8}{|c|}{ Clay } & \multicolumn{2}{|c|}{ Silt } & Sand & Soil texture \\
\hline Soil particles & \multicolumn{2}{|c|}{$\mathbf{5 4 . 9 3}$} & $\mathbf{1 6 . 7 8}$ & $\mathbf{2 8 . 2 9}$ & Clay sandy loam \\
\hline$\%$
\end{tabular}

Irrigation treatments started on $1^{\text {st }}$ May in both seasons. Four concentrations of lead (II) acetate $\left(\mathrm{Pb}\left(\mathrm{CH}_{3} \mathrm{COO}\right)_{2}\right) \quad 0,100,200$ and $300 \mathrm{ppm}$ were applied. The plants were irrigated three times per week, one irrigation level was used to keep the soil moisture at the field capacity of the mixture soil were divided into leaves and roots. They were then dried at $72^{\circ} \mathrm{C}$ in an oven until completely dried. The dried plant samples were ground to powder. Element extraction was done according to Piper (1947) method and the concentration of heavy metal 
Table (2): Total amount of water used for each plant (L/pot) in each treatment during the growing two seasons of 2017 and 2018.

\begin{tabular}{|c|c|c|c|c|c|c|c|}
\hline \multirow{2}{*}{$\begin{array}{c}\text { Field Capacity } \\
(\%)\end{array}$} & \multicolumn{7}{|c|}{ Months of the first and second seasons } \\
\cline { 2 - 8 } & May & June & July & August & September & October & Total \\
\hline $\mathbf{9 0 \%}$ & 4.50 & 5.50 & 6.50 & 7.50 & 6.50 & 5.50 & $\mathbf{3 6 . 0 0}$ \\
\hline
\end{tabular}

was determined using an atomic absorption spectrophotometer.

Available lead in soil samples were extracted by DPTA solution according to Lindsay and Norvell (1978) and determined by Inductively Coupled Plasma Spectrometry.

Transfer factor (TF) is calculated by the relation: the concentration of metal in the shoots and the concentration of metal in the soil (Chen et al., 2004). The transfer factor is a value used in evaluation studies on the impact of routine or accidental releases of pollutant into the environment.

The experimental design was split plot with three replicates. Each replicate contained three plants. The main plot was lead contaminated water concentration, while the subplot was citric acid treatments. Data were subjected to analysis of variance (ANOVA) using the SAS program, SAS Institute (SAS Institute, 2002). The Means of the individual factors and their interactions were compared by L.S.D test at 5\% level of probability according to Snedecor and Cochran (1989).

\subsection{Leaf characteristics:}

\section{RESULTS}

Data presented in Table (3) showed that plants irrigated with tap water had the highest number of leaves (46.60 and 65.60 leaves per plant), leaves area $\left(850.83\right.$ and $\left.942.23 \mathrm{~cm}^{2}\right)$ and leaves dry weights (7.63 and $11.41 \mathrm{~g}$ per plant) in the first and second seasons, respectively. On the other hand, the lowest number of leaves (41.77 and 61.99 leaves per plant), leaves area $\left(706.65\right.$ and $\left.828.88 \mathrm{~cm}^{2}\right)$ and leaves dry weight (7.10 and $10.39 \mathrm{~g}$ per plant) were obtained from plants irrigated with water with lead concentration at $300 \mathrm{ppm}$, in the first and the second seasons, respectively.

Also, the data presented in Table (3) showed that, the different citric acid treatments had a significant effect on Senecio cineraria plants. Foliar application of citric acid at $500 \mathrm{ppm}$ increased the number of leaves significantly (47.33 and 67.28 leaves per plant), the leaves area of (946.53 and $\left.1051.50 \mathrm{~cm}^{2}\right)$ and leaves dry weight $(8.20$ and 11.78 $\mathrm{g}$ per plant) in the first and second seasons, respectively, compared with the control plants that recorded the lowest leaves number (39.83 and 60.78 leaves per plant), leaves area (603.45 and 739.52 $\mathrm{m}^{2}$ ) and leaves dry weight (6.43 and $9.94 \mathrm{~g}$ per plant) in the two seasons, respectively.

Regarding the interaction between the effect of irrigation using water contaminated with lead and citric acid concentrations on the leaves characteristics, the data in Table (3) showed that the lowest mean values in the leaves number (36.66 and 59.16 leaves per plant), leaves area (569.92 and $\left.675.04 \mathrm{~m}^{2}\right)$ and leaves dry weight $(6.21$ and $9.58 \mathrm{~g}$ per plant) in the first and second seasons, respectively, were obtained in the plants irrigated with 300 ppm contaminated lead water and sprayed with tap water, while the highest mean values in the leaves number (48.33 and 68.16 leaves per plant), leaves area $\left(1039.39\right.$ and $\left.1100.27 \mathrm{~m}^{2}\right)$ and leaves dry weight (8.69 and $12.95 \mathrm{~g}$ per plant) were recorded in plants irrigated with water contaminated with at 0 ppm and sprayed with citric acid at 500 ppm, in the first and second seasons, respectively.

\subsection{Stem characteristics}

Data in Table (4) showed that increasing lead concentration in irrigation water caused a significant reduction in stem characteristics. The highest significant reduction was obtained from the concentration of $300 \mathrm{ppm}$ which gave tillers number (3.21 and 6.71 tillers per plant), stem height (4.63 and $6.49 \mathrm{~cm})$, stem diameter $(0.69$ and $0.92 \mathrm{~cm})$ and stem dry weight (1.31 and $1.50 \mathrm{~g}$ per plant) in the first and second seasons, respectively, compared with the control which gave tillers number $(3.82$ and 7.11tillers per plant), stem height (5.05 and 7.44 $\mathrm{cm})$, stem diameters $(0.80$ and $0.99 \mathrm{~cm})$ and stem dry weight (1.71 and $1.95 \mathrm{~g}$ per plant) in the first and the second seasons, respectively.

In contrast to the effect of lead treatments, citric acid treatments improved growth of Senecio cineraria plants. The highest significant number was obtained from plants sprayed with 500 ppm citric acid which gave tillers number per plant (4.32 and 7.49 tillers per plant), stem height (5.55 and $8.14 \mathrm{~cm})$, stem diameters $(0.83$ and $1.01 \mathrm{~cm})$ and stem dry weight (2.02 and $2.23 \mathrm{~g}$ per plant) in the first and the second seasons, respectively, compared with control value gave tillers number per plant (2.95 and 5.99 tillers per plant), stem height (4.22 and $5.85 \mathrm{~cm})$, stem diameters $(0.67$ and $0.90 \mathrm{~cm})$ and stem dry weight (1.06 and $1.25 \mathrm{~g}$ per plant) in the first and the second seasons, respectively.

Regarding the interaction between the effect of 
Table (3): Means of leaves characteristics of Senecio cineraria plants as influenced by lead concentrations in water irrigation, foliar application of citric acid and their interaction (Lead $\times$ citric acid) in the two seasons of 2017 and 2018.

\begin{tabular}{|c|c|c|c|c|c|c|c|}
\hline \multicolumn{2}{|c|}{ Treatments } & \multicolumn{2}{|c|}{$\begin{array}{c}\text { Number of leaves } \\
\text { per plant }\end{array}$} & \multicolumn{2}{|c|}{$\begin{array}{l}\text { Leaves area } \\
\qquad\left(\mathrm{cm}^{2}\right)\end{array}$} & \multicolumn{2}{|c|}{$\begin{array}{c}\text { Leaves dry } \\
\text { weight per plant } \\
\text { (g) }\end{array}$} \\
\hline $\begin{array}{c}\text { Lead } \\
(\mathbf{p p m})\end{array}$ & Citric acid (ppm) & 2017 & 2018 & 2017 & 2018 & 2017 & 2018 \\
\hline \multirow{3}{*}{0 ppm } & O ppm & 45.33 & 62.83 & 697.44 & 793.84 & 6.61 & 10.12 \\
\hline & $250 \mathrm{ppm}$ & 46.16 & 65.83 & 815.66 & 932.59 & 7.59 & 11.18 \\
\hline & 500 ppm & 48.33 & 68.16 & 1039.39 & 1100.27 & 8.69 & 12.95 \\
\hline \multicolumn{2}{|l|}{ Mean (Lead) } & 46.60 & 65.60 & 850.83 & 942.23 & 7.63 & 11.41 \\
\hline \multirow{3}{*}{100 ppm } & 0 ppm & 37.50 & 60.50 & 574.83 & 772.57 & 6.51 & 10.09 \\
\hline & 250 ppm & 43.33 & 64.16 & 831.49 & 919.65 & 7.36 & 10.66 \\
\hline & 500 ppm & 47.83 & 67.83 & 979.49 & 1099.56 & 8.18 & 11.56 \\
\hline \multicolumn{2}{|l|}{ Mean (Lead) } & 42.88 & 64.16 & 795.27 & 930.59 & 7.35 & 10.77 \\
\hline \multirow{3}{*}{200 ppm } & 0 ppm & 39.83 & 60.66 & 571.63 & 716.64 & 6.42 & 9.97 \\
\hline & $250 \mathrm{ppm}$ & 42.16 & 63.66 & 638.42 & 915.34 & 7.36 & 10.38 \\
\hline & $500 \mathrm{ppm}$ & 45.33 & 67.83 & 917.20 & 1003.85 & 8.07 & 11.38 \\
\hline \multicolumn{2}{|l|}{ Mean (Lead) } & 42.44 & 64.05 & 709.08 & 878.61 & 7.28 & 10.57 \\
\hline \multirow{3}{*}{300 ppm } & 0 ppm & 36.66 & 59.16 & 569.92 & 675.04 & 6.21 & 9.58 \\
\hline & 250 ppm & 40.83 & 61.50 & 699.98 & 809.30 & 7.23 & 10.38 \\
\hline & 500 ppm & 47.83 & 65.33 & 850.06 & 1002.32 & 7.87 & 11.23 \\
\hline \multicolumn{2}{|l|}{ Mean (Lead) } & 41.77 & 61.99 & 706.65 & 828.88 & 7.10 & 10.39 \\
\hline \multirow{3}{*}{$\begin{array}{l}\text { Mean } \\
\text { (Citric acid) }\end{array}$} & O ppm & 39.83 & 60.78 & 603.45 & 739.52 & 6.43 & 9.94 \\
\hline & $250 \mathrm{ppm}$ & 43.12 & 63.78 & 746.38 & 894.22 & 7.38 & 10.65 \\
\hline & 500 ppm & 47.33 & 67.28 & 946.53 & 1051.50 & 8.20 & 11.78 \\
\hline \multirow{3}{*}{ L.S.D. at 0.05} & Lead & 2.37 & 4.71 & 109.26 & 48.19 & 0.68 & 0.34 \\
\hline & Citric acid & 2.11 & $\mathbf{3 . 0 3}$ & 65.35 & 36.67 & 0.39 & 0.35 \\
\hline & Lead $\times$ Citric acid & 2.80 & 3.48 & 75.11 & 42.15 & 0.45 & 0.40 \\
\hline
\end{tabular}

Table (4): Means of stem characteristics of Senecio cineraria plants as influenced by Lead concentrations in water irrigation, foliar application of citric acid and their interaction (Lead $\times$ Citric acid) in the two seasons of 2017 and 2018.

\begin{tabular}{|c|c|c|c|c|c|c|c|c|c|}
\hline \multicolumn{2}{|c|}{ Treatments } & \multicolumn{2}{|c|}{$\begin{array}{l}\text { Tillers number } \\
\text { per plant }\end{array}$} & \multicolumn{2}{|c|}{$\begin{array}{l}\text { Stem height } \\
(\mathrm{cm})\end{array}$} & \multicolumn{2}{|c|}{$\begin{array}{l}\text { Stem diameter } \\
(\mathrm{cm})\end{array}$} & \multicolumn{2}{|c|}{$\begin{array}{l}\text { Stem dry } \\
\text { weight } \\
\text { (g) }\end{array}$} \\
\hline $\begin{array}{c}\text { Lead } \\
(\mathbf{p p m})\end{array}$ & Citric acid (ppm) & 2017 & 2018 & 2017 & 2018 & 2017 & 2018 & 2017 & 2018 \\
\hline \multirow{3}{*}{0 ppm } & 0 ppm & 3.16 & 5.83 & 4.41 & 6.25 & 0.77 & 0.92 & 1.22 & 1.40 \\
\hline & 250 ppm & 3.66 & 7.00 & 5.08 & 7.58 & 0.79 & 0.95 & 1.64 & 1.90 \\
\hline & 500 ppm & 4.66 & 8.50 & 5.66 & 8.50 & 0.86 & 1.10 & 2.27 & 2.56 \\
\hline \multicolumn{2}{|l|}{ Mean (Lead) } & 3.82 & 7.11 & 5.05 & 7.44 & 0.80 & 0.99 & 1.71 & 1.95 \\
\hline \multirow{3}{*}{100 ppm } & 0 ppm & 3.00 & 5.83 & 4.16 & 5.83 & 0.66 & 0.92 & 1.11 & 1.32 \\
\hline & 250 ppm & 3.50 & 7.00 & 4.75 & 7.08 & 0.75 & 0.95 & 1.53 & 1.78 \\
\hline & 500 ppm & 4.66 & 7.16 & 5.75 & 8.25 & 0.85 & 1.05 & 2.18 & 2.34 \\
\hline \multicolumn{2}{|l|}{ Mean (Lead) } & 3.72 & 6.66 & 4.88 & 7.05 & 0.75 & 0.97 & 1.60 & 1.81 \\
\hline \multirow{3}{*}{200 ppm } & 0 ppm & 3.00 & 6.16 & 4.25 & 5.75 & 0.64 & 0.90 & 1.03 & 1.27 \\
\hline & 250 ppm & 3.16 & 6.83 & 4.66 & 6.50 & 0.70 & 0.94 & 1.42 & 1.64 \\
\hline & 500 ppm & 4.33 & 7.16 & 5.66 & 8.16 & 0.84 & 0.96 & 1.86 & 2.08 \\
\hline \multicolumn{2}{|l|}{ Mean (Lead) } & 3.49 & 6.71 & 4.85 & 6.80 & 0.72 & 0.93 & 1.43 & 1.66 \\
\hline \multirow{3}{*}{300 ppm } & 0 ppm & 2.66 & 6.16 & 4.08 & 5.58 & 0.61 & 0.87 & 0.91 & 1.03 \\
\hline & $250 \mathrm{ppm}$ & 3.33 & 6.83 & 4.66 & 6.25 & 0.68 & 0.93 & 1.26 & 1.52 \\
\hline & 500 ppm & 3.66 & 7.16 & 5.16 & 7.66 & 0.80 & 0.96 & 1.77 & 1.97 \\
\hline \multicolumn{2}{|l|}{ Mean (Lead) } & 3.21 & 6.71 & 4.63 & 6.49 & 0.69 & 0.92 & 1.31 & 1.50 \\
\hline \multirow{3}{*}{$\begin{array}{l}\text { Mean } \\
\text { ( Citric acid) }\end{array}$} & 0 ppm & 2.95 & 5.99 & 4.22 & 5.85 & 0.67 & 0.90 & 1.06 & 1.25 \\
\hline & $250 \mathrm{ppm}$ & 3.41 & 6.91 & 4.78 & 6.85 & 0.73 & 0.94 & 1.46 & 1.71 \\
\hline & 500 ppm & 4.32 & 7.49 & 5.55 & 8.14 & 0.83 & 1.01 & 2.02 & 2.23 \\
\hline \multirow{3}{*}{ L.S.D. at 0.05} & Lead & 0.38 & 0.26 & 0.65 & 0.39 & 0.03 & 0.02 & 0.17 & 0.13 \\
\hline & Citric acid & 0.39 & 0.27 & 0.34 & 0.27 & 0.03 & 0.06 & 0.13 & 0.20 \\
\hline & Lead $\times$ Citric acid & 0.45 & 0.32 & 0.39 & 0.31 & 0.03 & 0.07 & 0.15 & $\mathbf{0 . 2 3}$ \\
\hline
\end{tabular}


irrigation using water contaminated with lead and citric acid concentrations on the stem characteristics, the data in Table (4) showed that the lowest mean values in the tillers number per plant (2.66 and 6.16 tiller per plant), stem height (4.08 and $5.58 \mathrm{~cm})$, stem diameter $(0.61$ and $0.87 \mathrm{~cm})$ and stem dry weight ( 0.91 and $1.03 \mathrm{~g}$ per plant) in the first and the second seasons, respectively, were obtained in plants irrigated with $300 \mathrm{ppm}$ contaminated lead water and sprayed with tap water, while the highest mean values in the tillers number per plant (4.66 and 8.50 tiller per plant), stem height $(5.66$ and $8.50 \mathrm{~cm})$ stem diameter $(0.86$ and $1.10 \mathrm{~cm})$ and stem dry weight $(2.27$ and $2.56 \mathrm{~g}$ per plant) in the first and the second season, respectively, were recorded in the plants irrigated with lead contaminated water at $0 \mathrm{ppm}$ and sprayed with citric acid at $500 \mathrm{ppm}$.

\subsection{Root characteristics}

Data presented in Table (5) showed that the tested lead concentrations in water irrigation significantly decreased the root characteristics of Senecio cineraria, compared with the plants irrigated with tap water (control). Plants irrigated with tap water had the highest mean root length of $(12.58$ and $18.24 \mathrm{~cm})$ and root dry weight of $(2.02$ and $3.19 \mathrm{~g}$ per plant) in the first and the second seasons, respectively, while the lowest root length of $11.72 \mathrm{~cm}$ in the first season and $17.08 \mathrm{~cm}$ in the second season were obtained from plants irrigated by the highest lead concentration 200 and 300 ppm and root dry weight of (1.87 and $2.84 \mathrm{~g}$ per plant) in the first and the second seasons, respectively, were obtained from plamts treated with lead at $300 \mathrm{ppm}$.

Data in Table (5) indicated that citric acid treatments had a significant effect on the root characteristics. Plants sprayed with citric acid at 500 ppm gave the tallest root length of (13.37 and 19.56 $\mathrm{cm})$ and root dry weight of (2.16 and $3.39 \mathrm{~g}$ per plant) in the first and the second seasons, respectively, compared with the control (10.93 and $15.95 \mathrm{~cm})$ and root dry weight of $(1.66$ and $2.66 \mathrm{~g}$ per plant) in the first and the second seasons, respectively.

Regarding the interaction between the effect of irrigation using water contaminated with lead and citric acid concentrations on the root characteristics, the data in Table (5) showed that the lowest mean values in the root length of $(10.83$ and $15.25 \mathrm{~cm})$, and root dry weight (1.61 and $2.40 \mathrm{~g}$ per plant) in the first and second seasons, respectively, were obtained for plants irrigated with $300 \mathrm{ppm}$ contaminated lead water and sprayed with tap water, while the highest mean values in the root length of $(13.83$ and $20.00 \mathrm{~cm})$ and root dry weight (2.19 and $3.53 \mathrm{~g}$ per plant) in the first and the

Table (5): Means of root characteristics of Senecio cineraria plants as influenced by Lead concentrations in water irrigation, foliar application of citric acid and their interaction (Lead $\times$ citric acid) in the two seasons of 2017 and 2018.

\begin{tabular}{|c|c|c|c|c|c|}
\hline \multicolumn{2}{|c|}{ Treatments } & \multicolumn{2}{|c|}{ Root length $(\mathrm{cm})$} & \multicolumn{2}{|c|}{ Root dry weight (g) } \\
\hline $\begin{array}{c}\text { Lead } \\
\text { (ppm) }\end{array}$ & Citric acid (ppm) & 2017 & 2018 & 2017 & 2018 \\
\hline \multirow{3}{*}{0 ppm } & 0 ppm & 11.08 & 16.41 & 1.78 & 2.93 \\
\hline & $250 \mathrm{ppm}$ & 12.83 & 18.33 & 2.07 & 3.13 \\
\hline & $500 \mathrm{ppm}$ & 13.83 & 20.00 & 2.19 & 3.53 \\
\hline \multicolumn{2}{|l|}{ Mean (Lead) } & 12.58 & 18.24 & 2.02 & 3.19 \\
\hline \multirow{3}{*}{100 ppm } & 0 ppm & 11.00 & 16.16 & 1.67 & 2.78 \\
\hline & $250 \mathrm{ppm}$ & 12.66 & 17.66 & 1.99 & 3.06 \\
\hline & $500 \mathrm{ppm}$ & 13.66 & 19.83 & 2.18 & 3.47 \\
\hline \multicolumn{2}{|l|}{ Mean (Lead) } & 12.44 & 17.88 & 1.95 & 3.10 \\
\hline \multirow{3}{*}{200 ppm } & O ppm & 10.83 & 16.00 & 1.61 & 2.54 \\
\hline & $250 \mathrm{ppm}$ & 11.50 & 17.33 & 1.90 & 3.06 \\
\hline & $500 \mathrm{ppm}$ & 12.83 & 19.75 & 2.15 & 3.37 \\
\hline \multicolumn{2}{|l|}{ Mean (Lead) } & 11.72 & 17.69 & 1.88 & 2.99 \\
\hline \multirow{3}{*}{300 ppm } & 0 ppm & 10.83 & 15.25 & 1.61 & 2.40 \\
\hline & $250 \mathrm{ppm}$ & 11.58 & 17.33 & 1.87 & 2.94 \\
\hline & $500 \mathrm{ppm}$ & 13.16 & 18.66 & 2.14 & 3.20 \\
\hline \multicolumn{2}{|l|}{ Mean (Lead) } & 11.85 & 17.08 & 1.87 & 2.84 \\
\hline \multirow{3}{*}{$\begin{array}{l}\text { Mean } \\
\text { (Citric acid) }\end{array}$} & O ppm & 10.93 & 15.95 & 1.66 & 2.66 \\
\hline & $250 \mathrm{ppm}$ & 12.14 & 17.66 & 1.95 & 3.04 \\
\hline & $500 \mathrm{ppm}$ & 13.37 & 19.56 & 2.16 & 3.39 \\
\hline \multirow{3}{*}{ L.S.D. at 0.05} & Lead & 0.50 & 1.58 & 0.09 & 0.17 \\
\hline & Citric acid & 0.60 & 1.30 & 0.11 & 0.09 \\
\hline & Lead $\times$ Citric acid & 0.68 & 1.49 & 0.12 & 0.10 \\
\hline
\end{tabular}


Table (6): Means of the chemical characteristics of Senecio cineraria plants as influenced by Lead concentrations in water irrigation, foliar application of citric acid and their interaction (Lead ×citric acid) in the two seasons of 2017 and 2018.

\begin{tabular}{|c|c|c|c|c|c|c|c|c|c|c|c|}
\hline \multicolumn{2}{|c|}{ Treatments } & \multicolumn{2}{|c|}{$\begin{array}{c}\text { Total } \\
\text { chlorophyll } \\
\text { content (SPAD) }\end{array}$} & \multicolumn{2}{|c|}{$\begin{array}{c}\text { Total } \\
\text { carbohydrates } \\
\text { percentage } \\
(\%)\end{array}$} & \multicolumn{2}{|c|}{$\begin{array}{c}\text { Lead content in } \\
\text { leaves } \\
(\text { ppm })\end{array}$} & \multicolumn{2}{|c|}{$\begin{array}{c}\text { Lead content in } \\
\text { stem } \\
(\text { ppm })\end{array}$} & \multicolumn{2}{|c|}{$\begin{array}{l}\text { Lead content in } \\
\text { roots } \\
(\mathrm{ppm})\end{array}$} \\
\hline $\begin{array}{c}\text { Lead } \\
(\mathbf{p p m})\end{array}$ & Citric acid (ppm) & 2017 & 2018 & 2017 & 2018 & 2017 & 2018 & 2017 & 2018 & 2017 & 2018 \\
\hline \multirow{3}{*}{ O ppm } & 0 ppm & 73.70 & 78.10 & 9.57 & 9.55 & 0.141 & 0.171 & 0.109 & 0.132 & 0.019 & 0.024 \\
\hline & $250 \mathrm{ppm}$ & 71.90 & 72.82 & 9.60 & 9.67 & 0.123 & 0.127 & 0.092 & 0.095 & 0.013 & 0.012 \\
\hline & $500 \mathrm{ppm}$ & 70.25 & 71.63 & 9.07 & 9.02 & 0.082 & 0.088 & 0.060 & 0.066 & 0.004 & 0.008 \\
\hline \multicolumn{2}{|l|}{ Mean (Lead) } & 71.95 & 74.18 & 9.41 & 9.41 & 0.115 & 0.128 & 0.087 & 0.097 & 0.012 & 0.014 \\
\hline \multirow{3}{*}{100 ppm } & O ppm & 63.58 & 64.48 & 8.52 & 8.50 & 0.309 & 0.311 & 0.286 & 0.289 & 0.116 & 0.120 \\
\hline & $250 \mathrm{ppm}$ & 67.70 & 69.03 & 8.84 & 8.80 & 0.283 & 0.274 & 0.236 & 0.233 & 0.067 & 0.072 \\
\hline & $500 \mathrm{ppm}$ & 66.58 & 67.15 & 8.67 & 8.66 & 0.146 & 0.165 & 0.122 & 0.137 & 0.033 & 0.036 \\
\hline \multicolumn{2}{|l|}{ Mean (Lead) } & 65.95 & 66.88 & 8.67 & 8.65 & 0.246 & 0.250 & 0.214 & 0.219 & 0.072 & 0.076 \\
\hline \multirow{3}{*}{200 ppm } & 0 ppm & 57.85 & 58.27 & 7.55 & 7.53 & 0.461 & 0.482 & 0.399 & 0.419 & 0.133 & 0.142 \\
\hline & $250 \mathrm{ppm}$ & 61.32 & 62.13 & 7.95 & 7.92 & 0.335 & 0.348 & 0.285 & 0.305 & 0.089 & 0.098 \\
\hline & $500 \mathrm{ppm}$ & 60.38 & 60.97 & 7.78 & 7.76 & 0.227 & 0.251 & 0.179 & 0.198 & 0.038 & 0.043 \\
\hline \multicolumn{2}{|l|}{ Mean (Lead) } & $\mathbf{5 9 . 8 5}$ & 60.45 & 7.76 & 7.73 & 0.341 & 0.360 & 0.287 & 0.307 & 0.086 & 0.094 \\
\hline \multirow{3}{*}{300 ppm } & O ppm & 46.38 & 47.23 & 6.78 & 6.72 & 0.567 & 0.620 & 0.481 & 0.543 & 0.151 & 0.191 \\
\hline & $250 \mathrm{ppm}$ & 52.65 & 53.85 & 7.13 & 7.09 & 0.370 & 0.395 & 0.317 & 0.337 & 0.102 & 0.107 \\
\hline & 500 ppm & 53.83 & 56.72 & 7.03 & 6.91 & 0.197 & 0.206 & 0.169 & 0.177 & 0.053 & 0.055 \\
\hline \multicolumn{2}{|l|}{ Mean (Lead) } & 50.95 & 52.60 & 6.98 & 6.90 & 0.378 & 0.407 & 0.322 & 0.352 & 0.102 & 0.117 \\
\hline \multirow{3}{*}{$\begin{array}{l}\text { Mean } \\
\text { (Citric acid) }\end{array}$} & O ppm & 60.37 & 62.02 & 8.10 & 8.07 & 0.369 & 0.396 & 0.318 & 0.345 & 0.104 & 0.119 \\
\hline & 250 ppm & 63.39 & 64.45 & 8.38 & 8.37 & 0.277 & 0.286 & 0.232 & 0.242 & 0.067 & 0.072 \\
\hline & $500 \mathrm{ppm}$ & 62.76 & 64.11 & 8.13 & 8.08 & 0.163 & 0.177 & 0.132 & 0.144 & 0.032 & 0.035 \\
\hline \multirow{3}{*}{ L.S.D. at 0.05} & Lead & 1.18 & 0.68 & $\mathbf{0 . 0 7}$ & $\mathbf{0 . 0 3}$ & 0.006 & 0.009 & 0.005 & 0.006 & 0.003 & 0.002 \\
\hline & Citric acid & 0.91 & 0.89 & 0.03 & 0.06 & 0.003 & 0.005 & 0.003 & 0.004 & 0.002 & 0.002 \\
\hline & Lead $\times$ Citric acid & 1.04 & 1.02 & 0.03 & 0.06 & 0.003 & 0.006 & 0.003 & 0.005 & 0.0008 & 0.0007 \\
\hline
\end{tabular}


second season, respectively, were recorded in the plants irrigated with lead water at $0 \mathrm{ppm}$ and sprayed with citric acid at $500 \mathrm{ppm}$.

\subsection{Chemical analysis}

\subsubsection{Total chlorophylls content (SPAD) units}

The results presented in Table (6) showed that the highest content of total chlorophylls was obtained in plants irrigated with tap water (71.95 and 74.18 SPAD) in the first and the second seasons, respectively. Increasing lead concentration in irrigation water resulted in steady significant reductions in the total chlorophylls content, which reached its lowest values after treatment with 300 ppm (50.95 and 52.60 SPAD) in the first and the second seasons, respectively.

Moreover, Table (6) illustrated that citric acid treatments had a clear positive effect on the total chlorophylls content. Mean values ranged from (60.37 and 62.02 SPAD) in the first and second seasons, respectively, in plants sprayed with $0 \mathrm{ppm}$ citric acid to (63.39 and 64.45 SPAD) in plants sprayed with $250 \mathrm{ppm}$ citric acid in the first and the second seasons, respectively.

Data in Table (6) clearly showed that a significant interaction was detected between the effects of plants irrigated with lead contaminated water and citric acid treatments. The highest total chlorophylls contents (73.70 and 78.10 SPAD) in the first and the second seasons, respectively, were formed by plants irrigated with tap water and sprayed with citric acid at $0 \mathrm{ppm}$. On the other hand, the lowest chlorophyll content (46.38 and 47.23 SPAD) were recorded in the first and the second seasons, respectively, for plants irrigated by $300 \mathrm{ppm}$ contaminated water combined with $0 \mathrm{ppm}$ citric acid treatment.

\subsubsection{Total carbohydrates percentage (\%)}

Table (6) showed that, the percentage of total carbohydrates in dried leaves of Senecio cineraria plants was decreased steadily with increasing lead concentration in the irrigation water. The highest percentages of carbohydrates were (9.41 and 9.41 $\%$ ) in the first and the second seasons, respectively, were found in the control plants, whereas the lowest mean values $(6.98$ and $6.90 \%)$ in the first and the second seasons, respectively, were found in plants irrigated with $300 \mathrm{ppm}$ lead concentration in water.

Table (6) showed that citric acid treatments had a clear positive effect on the percentage of total carbohydrates. Among the plants receiving the different citric acid treatments, plants sprayed with $250 \mathrm{ppm}$ citric acid had the highest carbohydrates percentage in their leaves of (8.38 and $8.37 \%$ ) in the first and the second seasons, respectively, compared with the control (8.10 and $8.07 \%)$ in the first and the second seasons, respectively.

Concerning the interaction effect between irrigation with lead contaminated water and citric acid treatments on the percentage of carbohydrates in leaves, Table (6) showed that the highest percentages of total carbohydrates $(9.60$ and $9.67 \%$ ) were formed by plants irrigated with tap water and sprayed with citric acid at $250 \mathrm{ppm}$. On the other hand, the lowest percentages of total carbohydrates were $(6.78$ and $6.72 \%)$ in the first and the second seasons, respectively, were obtained on plants irrigated by the highest lead concentration at $300 \mathrm{ppm}$ combined with citric acid at $0 \mathrm{ppm}$.

\subsubsection{Lead content in leaves, stem and root} (ppm)

The results presented in Table (6) showed that lead content in Senecio cineraria plants was increased steadily with increasing lead concentration in the irrigation water. The lowest lead content in leaves of $(0.115$ and $0.128 \mathrm{ppm})$, stem (0.087 and $0.097 \mathrm{ppm})$ and root $(0.012$ and $0.014 \mathrm{ppm})$ in the first and the second seasons, respectively, were found in the control plants, whereas the highest contents in leaves were $(0.378$ and $0.407 \mathrm{ppm})$, stem $(0.322$ and $0.352 \mathrm{ppm})$ and root $(0.102$ and $0.117 \mathrm{ppm})$ in the first and the second seasons, respectively, were found in plants irrigated with water containing the highest lead concentration of $300 \mathrm{ppm}$.

Table (6) illustrated that plant content of lead was slightly reduced by spraying the plants with $500 \mathrm{ppm}$ citric acid which gave a lead content in leaves of $(0.163$ and $0.177 \mathrm{ppm})$, stem $(0.132$ and $0.144 \mathrm{ppm})$ and root $(0.032$ and $0.035 \mathrm{ppm})$ in the first and second seasons, respectively, while the highest values in leaves of $(0.369$ and $0.396 \mathrm{ppm})$, stem $(0.318$ and $0.345 \mathrm{ppm})$ and root $(0.104$ and $0.119 \mathrm{ppm})$ in the first and the second seasons, respectively were recorded for plants unsprayed with citric acid.

For the interaction effects between plant irrigation with lead contaminated water and citric acid treatments data presented in Table (6) showed that the highest lead values in leaves were $(0.567$ and $0.620 \mathrm{ppm})$, stem $(0.481$ and $0.543 \mathrm{ppm})$ and root $(0.151$ and $0.191 \mathrm{ppm})$ in the first and the second seasons, respectively, were obtained from plants irrigated with lead contaminated water at 300 ppm and unsprayed with citric acid. On the other hand, the lowest values in leaves were $(0.082$ and $0.088 \mathrm{ppm})$, stem $(0.060$ and $0.066 \mathrm{ppm})$ and root $(0.004$ and $0.008 \mathrm{ppm})$ in the first and the second seasons, respectively, were obtained from plants 
irrigated with tap water and sprayed with citric acid at $500 \mathrm{ppm}$.

\subsection{4.. Lead content in soil samples (ppm)}

Data in Table (7) showed that the lowest average of lead content was observed in untreated soil, while the highest average of lead content was observed in soil reprieving $300 \mathrm{ppm}$ lead and 500 ppm citric acid.

Table (7): Average of lead content in soil samples as influenced by lead concentrations in irrigation water and foliar application of citric acid on Senecio cineraria leaves at the end of both seasons (2017 and 2018).

\begin{tabular}{|c|c|c|c|}
\hline \multicolumn{2}{|c|}{ Treatments } & \multicolumn{2}{|c|}{$\begin{array}{l}\text { Lead content in soil } \\
\text { (ppm) }\end{array}$} \\
\hline $\begin{array}{l}\text { Lead } \\
\text { (ppm) }\end{array}$ & $\begin{array}{l}\text { Citric } \\
\text { acid } \\
(\mathbf{p p m})\end{array}$ & 2017 & 2018 \\
\hline \multirow{3}{*}{ 0 } & 0 & 1.423 & 1.546 \\
\hline & 250 & 1.546 & 1.665 \\
\hline & 500 & 1.609 & 1.732 \\
\hline \multirow{3}{*}{100} & 0 & 1.584 & 1.705 \\
\hline & 250 & 1.665 & 1.788 \\
\hline & 500 & 1.738 & 1.862 \\
\hline \multirow{3}{*}{200} & 0 & 1.696 & 1.819 \\
\hline & 250 & 1.768 & 1.883 \\
\hline & 500 & 1.850 & 1.977 \\
\hline \multirow{3}{*}{300} & 0 & 1.785 & 1.908 \\
\hline & 250 & 1.888 & 2.011 \\
\hline & 500 & 1.945 & 2.066 \\
\hline
\end{tabular}

\subsubsection{Transfer factor to leaves (TFL), stem (TFS) and root (TFR)}

From the data presented in Table (8), it can be seen that the transfer factor in Senecio cineraria plants was decreased steadily with increasing the lead concentration in the irrigation water. Accordingly, the lowest lead value in the leaves (0.075 and 0.078), in the stems (0.057 and 0.059) and in the root the $(0.007$ and 0.008$)$ in the first and second seasons, respectively, were found in plants irrigated with water containing lead concentration 0 ppm, whereas the highest value in the leaves $(0.204$ and 0.206$)$, in the stem the $(0.174$ and 0.178$)$ and in the roots $(0.054$ and 0.059$)$ were found in plants irrigated with water containing lead concentration at $300 \mathrm{ppm}$, in the first and the second seasons, respectively.

The results in Table (8) also showed that the transfer factor was reduced steadily with increasing citric acid concentration. Accordingly, the highest lead value in the leaves $(0.220$ and 0.220$)$, in the stems $(0.190$ and 0.191$)$ and in the roots $(0.062$ and 0.065 ) in the first and the second seasons, respectively, were recorded for the control plants, whereas the plants sprayed with the highest citric acid concentration $500 \mathrm{ppm}$ had the lowest lead value in the leaves (0.0.089 and 0.090), in the stem $(0.072$ and 0.074$)$ and in the roots $(0.016$ and 0.017$)$ in the first and the second seasons, respectively.

Regarding the interaction between the effect of irrigation using water contaminated with lead and citric acid concentrations on the transfer factor, the data in Table (8) showed that the highest mean values in the dried leaves $(0.317$ and 0.324$)$, in the stems $(0.269$ and 0.284$)$ and in the roots $(0.084$ and 0.099) were obtained in plants irrigated with 300 ppm contaminated lead water and sprayed with tap water, in the first and the second seasons, respectively, while the lowest mean values in the leaves $(0.050$ and 0.050$)$, in the stems $(0.037$ and $0.038)$ and in the roots $(0.002$ and 0.004 were recorded in plants irrigated with lead contaminated water at $0 \mathrm{ppm}$ and sprayed with citric acid at 500 $\mathrm{ppm}$, ) in the first and second season, respectively.

\section{DISCUSSION}

This study revealed that at high heavy metal concentrations, the biomass was significantly reduced. The leaves growth was more sensitive than other parts, as leaves rapidly absorbed water and had higher accumulations of heavy metal elements. The results presented by this study were in agreement with earlier reports on other plants, such as the aquatic plant Wolffia arrhiza (Piotrowska et al., 2010), barley (Hordeum vulgare) (Tiryakioglu et al., 2006) and Typha angustifolia (Bah et al., 2011).

Plants can tolerate lead either by external exclusion or internal tolerance. By the external exclusion, lead ions are excluded from entering the plant cells and thus lead cannot accumulate in the organelles and excess lead ions are removed out of the plant cell (Sharma and Dubey 2005). The internal tolerance of lead is mainly due to the synthesis of organic lead compounds (cysteine, glutathione, phytochelatin, etc. and eventually the lead ions are transformed in the cell into chemically bound structures with lower toxicity, alleviating the $\mathrm{Pb}$ toxic effect on the plants tissues (Pourrut et al., 2011).

Lead can damage the ultrastructures of the plants organs, tissues, chloroplast, mitochondria, nucleus, cell wall, and cell membrane. This damage can cause a loss of organelle function, and can eventually affect the normal physiological functions that include photosynthesis, respiration, protein synthesis, and cell division within the plant (Salazar and Pignata, 2014). 
Table (8): Means of transfer factor to leaves, stems and roots of Senecio cineraria plants as influenced by Lead, citric acid and their combinations (Lead $\times$ Citric acid) in the two season 2018.

\begin{tabular}{|c|c|c|c|c|c|c|c|}
\hline \multicolumn{2}{|c|}{ Treatments } & \multicolumn{2}{|c|}{$\begin{array}{c}\text { Transfer } \\
\text { factor to leaves } \\
\text { (TFL) }\end{array}$} & \multicolumn{2}{|c|}{$\begin{array}{c}\text { Transfer factor to } \\
\text { stem } \\
\text { (TFS) }\end{array}$} & \multicolumn{2}{|c|}{$\begin{array}{l}\text { Transfer factor to } \\
\text { roots } \\
\text { (TFR) }\end{array}$} \\
\hline $\begin{array}{l}\text { Lead } \\
(\mathbf{p p m})\end{array}$ & $\begin{array}{c}\text { Citric acid } \\
(\mathrm{ppm})\end{array}$ & 2017 & 2018 & 2017 & 2018 & 2017 & 2018 \\
\hline \multirow{3}{*}{000} & $\mathbf{0}$ & 0.098 & 0.110 & 0.076 & 0.084 & 0.013 & 0.014 \\
\hline & 250 & 0.079 & 0.075 & 0.059 & 0.057 & 0.008 & 0.006 \\
\hline & 500 & 0.050 & 0.050 & 0.037 & 0.038 & 0.002 & 0.004 \\
\hline \multicolumn{2}{|c|}{ Mean (Lead) } & 0.075 & 0.078 & 0.057 & 0.059 & 0.007 & 0.008 \\
\hline \multirow{3}{*}{100} & $\mathbf{0}$ & 0.194 & 0.182 & 0.180 & 0.169 & 0.073 & 0.070 \\
\hline & 250 & 0.169 & 0.153 & 0.141 & 0.130 & 0.039 & 0.040 \\
\hline & 500 & 0.084 & 0.088 & 0.070 & 0.073 & 0.018 & 0.018 \\
\hline \multicolumn{2}{|c|}{ Mean (Lead) } & 0.149 & 0.141 & 0.130 & 0.124 & 0.043 & 0.042 \\
\hline \multirow{3}{*}{200} & $\mathbf{0}$ & 0.271 & 0.264 & 0.235 & 0.230 & 0.078 & 0.078 \\
\hline & 250 & 0.189 & 0.184 & 0.161 & 0.161 & 0.050 & 0.052 \\
\hline & 500 & 0.122 & 0.126 & 0.096 & 0.100 & 0.020 & 0.021 \\
\hline \multicolumn{2}{|c|}{ Mean (Lead) } & 0.194 & 0.191 & 0.164 & 0.163 & 0.049 & 0.050 \\
\hline \multirow{3}{*}{300} & $\mathbf{0}$ & 0.317 & 0.324 & 0.269 & 0.284 & 0.084 & 0.099 \\
\hline & 250 & 0.195 & 0.196 & 0.167 & 0.167 & 0.053 & 0.052 \\
\hline & 500 & 0.101 & 0.099 & 0.086 & 0.085 & 0.027 & 0.026 \\
\hline \multicolumn{2}{|c|}{ Mean (Lead) } & 0.204 & 0.206 & 0.174 & 0.178 & 0.054 & 0.059 \\
\hline \multirow{3}{*}{$\begin{array}{l}\text { Mean } \\
\text { (Citric acid) }\end{array}$} & $\mathbf{0}$ & 0.220 & 0.220 & 0.190 & 0.191 & 0.062 & 0.065 \\
\hline & 250 & 0.158 & 0.152 & 0.132 & 0.128 & 0.037 & 0.037 \\
\hline & 500 & 0.089 & 0.090 & 0.072 & 0.074 & 0.016 & 0.017 \\
\hline \multirow{3}{*}{$\begin{array}{l}\text { L.S.D. at } \\
\text { 0.05 }\end{array}$} & Lead & 0.0039 & 0.0050 & 0.0030 & 0.0034 & 0.0016 & 0.0016 \\
\hline & Citric acid & 0.0019 & 0.0033 & 0.0020 & 0.0027 & 0.0014 & 0.0012 \\
\hline & Lead $\times$ Citric acid & 0.0007 & 0.0038 & 0.0007 & 0.0009 & 0.0004 & 0.0004 \\
\hline
\end{tabular}

Concerning the treatments and the control samples, at a preliminary stage, one should note that the transfer factor of most treatments is lower than one for lead; which means that the physiological need of the plant for these elements is rather limited.

Trace elements translocate from roots to shoots via a number of physiological processes, including metal unloading into root xylem cells, long-distance carrying from the xylem to the shoots and metal reabsorption, by leaf mesophyll cells, from the xylem stream. Once the trace metals have been unloaded into the xylem vessels, the metals are carried to the shoots by the transpiration stream (Blaylock and Huang, 2000).

For the effect of citric acid, it is observed that there is a significant increase in all vegetative parameters, chlorophyll content, carbohydrate percentage, significant decrease in lead content in leaves and roots and decrease in lead content. This may be due to that application of citric acid with any of the concentrations of lead which led to a statistical decrease in the uptake of lead. This decrease in uptake of lead in the presence of citric acid resulted in the formation of citric acid-lead complexes that inhibited the uptake (Chen et al., 2003). The decrease in lead uptake helped to overcome the negative effects of lead on the previous studied parameters. These results are in agreement with those mentioned by (Talebi et al., 2014) on Gazania plants and Jaafari and Hadavi (2012) on Ocimum basilicum L.

We conclude that we can use Senecio cineraria plants as lead phytoremediation plant without spraying with citric acid and if we want to use Senecio cineraria as an ornamental plant and the irrigation water is contaminated with lead we can spray the plants with citric acid to overcome the negative effect of lead.

\section{CONCLUSIONS}

The concentrations of heavy metals increase in the environment from year to year. Therefore decontamination of heavy metal-contaminated water and soils is very important for maintenance of environmental health and ecological restoration. Phytoremediation is a new cleanup concept that 
involves the use of plants to clean or stabilize contaminated environments. Phytoremediation of metals is the most effective plant-based method to remove pollutants from contaminated areas. This green technology can be applied to remediate the polluted soils without creating any destructive effect of soil structure. Some specific plants, such as some ornamental species, have been proven to have noticeable potential to absorb toxic heavy metals.

\section{REFERENCES}

Bah A.M., Dai H., Zhao J., Sun H., Cao F., Zhang G. and Wu F. (2011). Effects of cadmium, chromium and lead on growth, metal uptake and antioxidative capacity in Typha angustifolia. Biol. Trace Elem. Res., 142: $77-$ 92.

Blaylock M.J. and Huang J.W. (2000). Phytoextraction of Metals. Phytoremediation of Toxic Metals: Using Plants to Clean up the environment. Raskin, I. and B.D. Ensley. (Eds.) (Eds.) John Wiley and Sons, Inc, Toronto,Canada, p. 303.

Boussama N., Ouariti, A., Suzuki A. and Ghorbal, M.H. (1999). Cd-stress on nitrogen assimilation. J. Plant Physiol., 155, 310-317.

Chen Y., Shen Z. and Li X. (2004). The use of vetiver grass (Vetiveria zizanioides) in the phytoremediation of soils contaminated with heavy metals. Appl. Geochem., 19: 15531565.

Chen Y.X., Lin Q., Luo Y.M., He Y.F., Zhen S.J., Yu Y.L., Tian G.M. and Wong M.H. (2003). The role of citric acid on the phytoremediation of heavy metal contaminated soil. Chemosphere, 50:507811.

Choruk K., Kurukote J., Supprung P. and Vetayasuporn S. (2006). Perennial plants in the phytoremediation of lead-contaminated soils. Biotech., 5 (1):1-4.

Christoper B. (2003). RHS A-Z Encyclopedia of Garden Plants. $3^{\text {rd }}$ ed. Dorling Kindersley, London.UK.,ISBN 0-7513-3738-2.

Cuypers A., Vangronsveld J. and Clijsters H. (1999). The chemical behaviour of heavy metals plays a prominent role in the induction of oxidative stress. Free Radical Res. 31, 539-543.

Da Silva J.A.T. (2003). The cut flower: Postharvest considerations, J. Biol. Sci., 3(4): 406-442.

Dubios M., Gilles K., Hamlton J., Rebers P. and Smith F. (1956). Colourimetric method for determination of sugars and related substances. Analyt. Chem., 28(3): 350- 356.
Israelsen O. and Hansen V. (1962). Irrigation, Principles and Practices. John Wiley and Sons, Inc. New York,USA.

Jaafari N. and Hadavi E. (2012). "Growth and essential oil yield of basil (Ocimum basilicum L.) as affected by foliar spray of citric acid and salicylic acid. Zeitschrift fur Arznei- und Gewurzpflanzen, 17 (2): 80-83.

Jackson N.L. (1958). Soil Chemical Analysis. Constable. Ltd. Co., London, UK, 498 p.

Koller H. R. (1972). Leaf area, leaf weight relationship in the soybean canopy. Crop Sci., 12: $180-183$.

Kurepa J., Van Montagu M. and Inze D. (1997). Expression of $\operatorname{sod} C p$ and $\operatorname{sodB}$ genes in Nicotiana tabacum: Effects of light and copper excess. J. Exp. Bot., 48, 2007-2014.

Lindsay W.L. and Norvell W.A. (1978). Development of a DTPA soil test for zinc, iron, manganese and copper. Soil Sci. Soc. Am. J., 42: 421-428.

Mahler R.J., Bingham F.T. and Chang A.C. (1981). Effect of heavy metal pollution on plants. Appli. Sci., 1:72-109.

Malecka A., Jarmuszkiewicz V. and Tomaszewska B. (2001). Antioxidative defense to lead stress in subcellular compartments of pea root cells. Acta Biochem. (3):687-698.

Piper O.S. (1947). Soil and Plant Analysis. Adelaide Univ., Adelaide,Australia: 258-275.

Piotrowska A. A., Bajguz B. GodlewskaZylkiewicz and Zambrzycka E. (2010). Changes in growth, biochemical components, and antioxidant activity in aquatic plant Wolffiaarrhiza (Lemnaceae) exposed to cadmium and lead. Arch.Environ. Contam. Toxicol., 58: 594-604.

Pourrut B., Shahid M., Dumat C., Winterton P. and Pinelli E. (2011). Lead uptake, toxicity, and detoxification in plants. Rev. Environ. Contam, 213:113-136.

Prasad K.V.S.K., Paradha S. P. and Sharmila P. (1999). Concerted action of antioxidant enzymes and curtailed growth under zinc toxicity in Brassica juncea. Environ. Exp. Bota. 42, 1-10.

Prasad M.N.V. (2005). Cadmium ophilous plants and their significance in phytotechnologies. Braz. J. Plant Physiol., 17: 113-128.

Rauser W.R. (1995). Phytochelatins and related peptides, structure, biosynthesis and function. Plant Physiol., 109, 1141-1149.

Salazar M.J. and Pignata M.L. (2014). Lead accumulation in plants grown in polluted soils. Screening of native species for 
phytoremediation. J. Geochem. Explor., 137:29-36.

SAS Institute (2002). SAS User Guide and Program 20 Version 9.0.38. Cary, NC27513, USA.

Sharma B.D., Mukhopadhyay S.S. and Katyal J.C. (2006). Distribution of total and DTPAextractable zinc, copper, manganese and iron in vertisols of India. Commun. Soil Sci. Plant Anal., 37: 653-672.

Sharma P. and Dubey R.S. (2005). Lead toxicity in plants. B. J. Plant Physiol., 17:35-52.

Snedecor G. W. and Cochran W. (1989). Statistical Methods, $8^{\text {th }}$ ed. Edition, Iowa State University Press, Iowa, USA.

Talebi M., Hadavi E. and Jaafari N. (2014). Foliar sprays of citric acid and malic acid modify growth, flowering, and root to shoot ratio of Gazania (Gazania rigens L.): A Comparative Analysis by ANOVA and
Structural Equations Modeling. Adv. Agric. Article ID, 147278: 1-6.

Tiryakioglu M., Eker S., Ozkutlu F., Husted S. and Cakmak I. (2006). Antioxidant defense system and cadmium uptake in barley genotypes differing in cadmium tolerance. J. Trace Elem. Med. Biol., 20: 181-189.

Unhalekhana U. and Kositanont C. (2008). Distribution of cadmium in soil around zinc mining area. Thai J. of Toxicol., 23:170-174.

Wills R., Lee T., Graham D., McGlasson W. and Hall E. (1981). Post-harvest: an Introduction to the Physiology and handling of fruit and vegetables. Kensington, NSW, New South Wales Univ. Press, Aust.

Yadava U. (1986). A rapid and nondestructive method to determine chlorophyll in intact leaves. Hort. Sci., 21(6): 1449-1450.

$$
\begin{aligned}
& \text { إستخدام نباتات الثيرانيا المرشوشة بحامض الستريك على العلاج النباتى للتلوث بالرصاص } \\
& \text { *نادر أحمد الثنهورى ـ أمانى إسماعيل آدم* ـ فاطمة الزهراء حسين التونى } \\
& \text { قسم بحوث الحدائق النباتية و * قسم بحوث نباتات الزينة }
\end{aligned}
$$

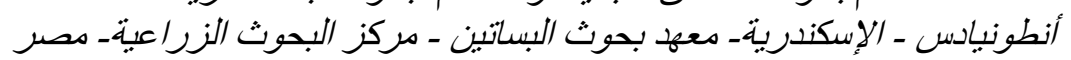

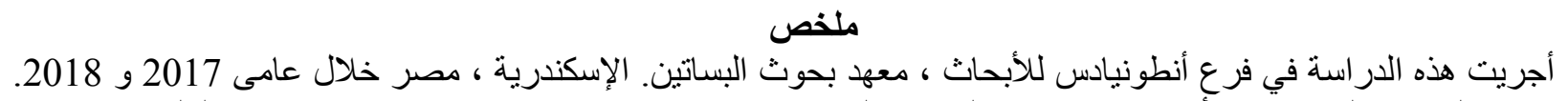

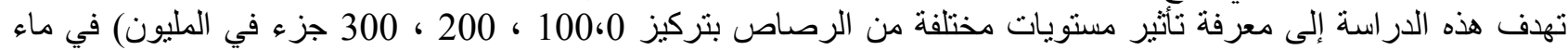

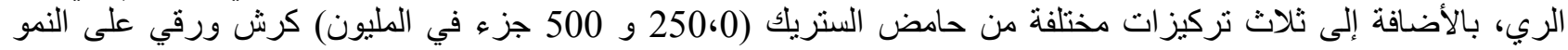

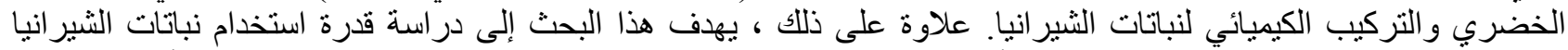

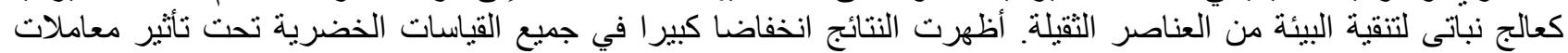

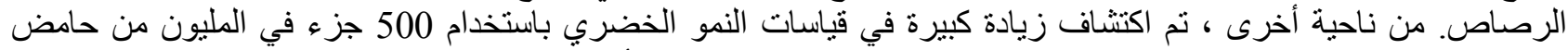

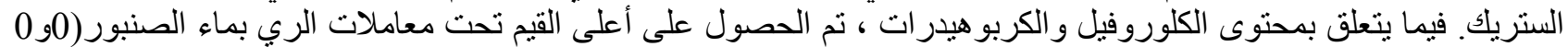

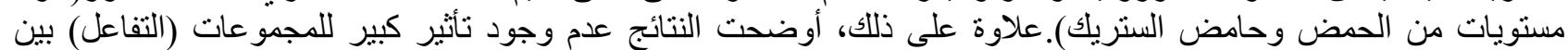

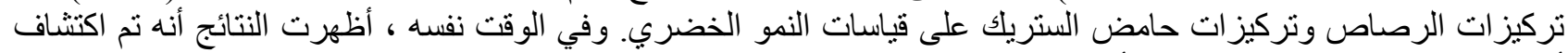

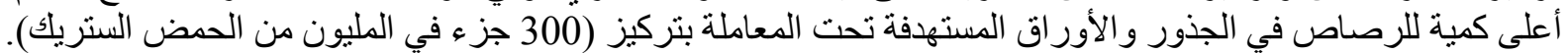

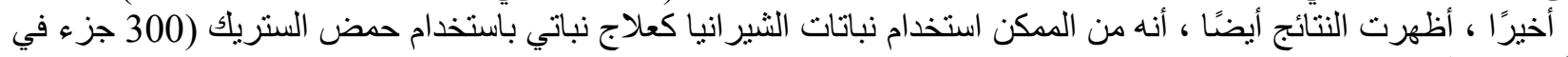

